\title{
PENGARUH KOMPOSISI MEDIA TANAM DAN APLIKASI Azotobacter chroococcum TERHADAP PERTUMBUHAN STEK TANAMAN TIN (Ficus carica L.)
}

\author{
The Effect of Planting Media and The Aplication of Azotobacter chroococcum on Growth of \\ Tin Graft (Ficus carica L.)
}

Saniar Fauza, T. Sabrina, Hamidah Hanum

Program Studi Pasca Sarjana Fakultas Pertanian USU, Medan 20155

*Corresponding author: tdjunita14@yahoo.com

\begin{abstract}
ABSTRAK
Perbanyakan tanaman tin umumnya dilakukan dengan stek batang atau cabang. Pertumbuhan stek dipengaruhi oleh faktor luar dan faktor dari dalam. Faktor luar diantaranya media tanam dan faktor dalam yaitu kandungan hormon, salah satu bakteri fiksasi $\mathrm{N}_{2}$ non simbiotik yang dapat mensekresi hormon pertumbuhan tanaman yaitu bakteri Azotobacter chroococcum. Penelitian dilakukan untuk menentukan komposisi media tanam dan aplikasi Azotobacter chroococcum dalam pengembangan pembibitan stek tanaman tin (Ficus carica L.). Penelitian telah dilaksanakan di desa Gampong Raya Dagang Kecamatan Peusangan, Kabupaten Bireuen, Provinsi Aceh dari bulan November 2014 sampai dengan Juni 2015. Rancangan yang digunakan adalah Rancangan Acak Kelompok Faktorial, Faktor pertama yaitu media tanam (M) terdiri dari enam komposisi : (top soil + pasir + Pupuk kandang sapi), (top soil + pasir + kompos jerami $\mathrm{C} / \mathrm{N}<20$ ), (top soil + pasir + kompos jerami $\mathrm{C} / \mathrm{N}>20)$, (top soil + pasir + zeolit $5 \mathrm{~g}$ ), (top soil + pasir + kompos jerami $\mathrm{C} / \mathrm{N}<20+5 \mathrm{~g}$ zeolit), (top soil + pasir + kompos jerami $\mathrm{C} / \mathrm{N}>20+5 \mathrm{~g}$ zeolit), Faktor kedua yaitu aplikasi bakteri Azotobacter chroococcum (A) terdiri dari : (tanpa aplikasi A.chroococcum) dan (aplikasi A.chroococcum). Hasil penelitian menunjukkan bahwa interaksi antara komposisi media tanam dan aplikasi A.chroococcum berpengaruh nyata terhadap $\mathrm{pH}$ media, kadar $\mathrm{N}$ daun dan berat kering daun, dan tidak berpengaruh nyata terhadap panjang cabang, jumlah ruas,waktu munculnya tunas , karbon organik dan $\mathrm{N}$ total media. Komposisi media tanam top soil + pasir + kompos jerami $\mathrm{C} / \mathrm{N}>20$ $+5 \mathrm{~g}$ zeolit $+5 \mathrm{ml}$ A.chroococcum dapat memberikan efek yang lebih baik terhadap pertumbuhan tanaman tin dibandingkan dengan komposisi media lain.
\end{abstract}

Kata Kunci : Stek tin, Komposisi Media tanam, Azotobacter chroococcum

\begin{abstract}
Tin propagation is generally done by stem graft or branches. Stem graft growth is influenced by external and internal factors. The external factor includes growing media while the inside factor includes contains of hormone, one of Fixation bacteria $\mathrm{N}_{2}$ non symbiotic can secrete growth of hormone of the plant, that is A.chroococcum. This research was done to study the effect of planting media composition and the application of A.chroococcum on the breeding development of graft plant which was carried out at Raya Dagang village Peusangan SubDistrict, Bireuen District, Aceh Province from March $4^{\text {th }}$ until June $4^{\text {th }} 2015$. The design used was The Randomly Factorial Group Design, the first factor was Planting Media (M) consisting of (Top soil + sand + dung cow), (Top soil + sand + paddy straw compost $\mathrm{C} / \mathrm{N}<200$, (Top soil + sand + paddy straw compost $\mathrm{C} / \mathrm{N}>20\}$, M3 (Top soil + sand +5 g zeolite), (Top soil + sand + paddy straw compost $\mathrm{C} / \mathrm{N}<20+5 \mathrm{~g}$ zeolite), (Top soil + sand + paddy straw compost $\mathrm{C} / \mathrm{N}>$ $20+5 \mathrm{~g}$ zeolite), the second factor was the application of A.chroococcum (A) consisting of A0
\end{abstract}


(without the application of A. chroococcum) and A1 (the application A. chroococcum). The result of the research shows that interaction ofplanting media composition factor and application $A$. chroococcum show a significant effect on a week $\mathrm{pH}$ media,concentration nitogen on leafes and leafe dry weight,and not significant effect on carbon organic, $\mathrm{N}$ total, length of branch, the number of internode, the number of internode. The best composition of growing media was top soil + paddy straw compost $\mathrm{C} / \mathrm{N}>20$ with the addition $5 \mathrm{~g}$ zeolit $+5 \mathrm{ml}$ A. chroococcum .

Key words : Graft Tin, Planting Media Composition, Azotobacter chroococcum

\section{PENDAHULUAN}

Tanaman Tin/Ara (Ficus carica L.) merupakan tanaman khas Timur Tengah yang saat ini tengah dibudidayakan di Indonesia meskipun masih tergolong langka, tanaman ini telah dikenal sebagai tanaman yang mempunyai khasiat. Tanaman asal Timur Tengah menyebar sampai ke daratan Eropa dan Amerika yang dikenal dengan nama "Figs". Tanaman ini sendiri di Indonesia masih kurang dikenal.Kandungan vitamin buah tin tidak kalah dengan apel dan jeruk. Disebutkan penelitian California Figs Nutritional Information, buah tin mengandung serat (Dietary Fiber) yang sangat tinggi. Setiap 100 gram buah tin kering terkandung 12.2 gram serat, sedangkan apel hanya mengandung 2 gram dan jeruk mengandung 1.9 gram (Supriadi, 2006).Perbanyakan tanaman ini dapat melalui biji, stek ataupun cangkok (Sobir dan Amalya, 2011). Morton (1987), menyatakan cara yang paling banyak digunakan untuk perbanyakan tin adalah dengan menggunakan stek. Keberhasilan stek dalam membentuk akar dipengaruhi oleh umur tanaman, fase pertumbuhan dan perbedaan bagian tanaman yang digunakan sebagai bahan stek (Syakir et al., 1992). Faktor lain yang juga menentukan keberhasilan stek untuk berakar adalah pemilihan dan pengelolaan media tanam. Tanaman tin yang diperbanyak dengan cara penyetekan harus ditumbuhkan pada media tanam yang dapat menunjang pembentukan akar dan tunas sehingga diperoleh tanaman baru yang identik dengan induknya (Flaishman et al., 2008). Informasi tentang komposisi media tanam yang tepat terhadap pertumbuhan stek tanaman tin masih sangat kurang.Media tumbuh yang baik harus memenuhi beberapa persyaratan, salah satunya tidak terlalu padat, sehingga dapat membantu pembentukan dan perkembangan akar tanaman.Selain itu, juga mampu menyimpan air dan unsur hara secara baik, mempunyai aerasi yang baik, tidak menjadi sumber penyakit serta mudah didapat dengan harga yang relatif murah. Upaya pembibitan tanaman yang menunjang pertumbuhan akar yang sehat dengan cara penggunaan media yang baik bagi akar dan mendukung perkembangan akar (struktur tanah porous). Media tanam dengan kondisi demikian dapat dibuat dengan menambahkan pupuk organik (pupuk kandang sapi, kompos jerami). Salah satu pupuk organik yang dapat digunakan adalah jerami padi yang telah dikomposkan dengan stater Trichoderma sp yang disebut trichokompos jerami padi.Jerami padi merupakan salah satu limbah pertanian yang ketersediaannya masih sangat banyak dan pengelolaannya masih kurang diperhatikan.Penambahan jerami padi dapat menambah bahan organik tanah yang berguna unntuk memperbaiki sifat fisik, kimia dan biologi tanah. Trichokompos jerami padi dengan teknologi pengomposan yang menggunakan Trichoderma sp sebagai dekomposer dapat mempercepat proses pengomposan. Zeolit dapat digunakan untuk memperbaiki kesuburan 
aktual tanah dan dapat berperan sebagai bahan pembenah tanah dan juga ditambahkan ke media tanam. Zeolit juga merupakan bahan pembenah tanah yang dapat memegang dan melepaskan air seperlunya dan menghambat kekurangan air.Selain itu zeolit berguna dalam memperbaiki tata udara dan drainase tanah serta meningkatkan kapasitas tukar kation tanah, karena zeolit mengandung basa $\mathrm{K}$, $\mathrm{Ca}$, dan $\mathrm{Mg}$ yang dapat dipertukarkan (Bernas et al., 2005).Penambahan input

\section{METODE PENELITIAN}

Penelitian ini dilaksanakan di Desa Gampong Raya Dagang Kecamatan Peusangan KabupatenBireuen, Provinsi Nanggroe Aceh Darussalam pada bulan November 2014 sampai dengan Juni 2015. Bahan yang digunakan adalah stek tanaman tin varietas Green Jordan yang sudah di tanam di kebun, inokulum A. chroococcum , decomposer T. harzianum, top soil, pasir sungai, kompos jerami, tepung zeolit, polybag, paranet $25 \%$, ember, fungisida Antracol. Alat yang digunakan antara lain: gergaji, cangkul, gembor, meteran, penggaris, gunting stek, pisau, timbangan digital, petri dish, gelas ukur, pipet dan alat tulis .Disain penelitian yang digunakan adalah rancangan acak kelompok faktorial (RAK) dengan dua faktor. Faktor 1: media tanamterdiri dari 6 komposisi yaitu $\mathrm{M}_{0}=$ top soil + pasir + pupuk kandang (1: $1: 1$, $\mathrm{w} / \mathrm{w} / \mathrm{w}) \mathrm{M}_{1}=$ top soil + pasir + kompos jerami rasio $\mathrm{C} / \mathrm{N}<20 \quad(1: 1: 1, \mathrm{w} / \mathrm{w} / \mathrm{w})$, $\mathrm{M}_{2}=$ top soil + pasir + kompos jerami rasio $\mathrm{C} / \mathrm{N}>20(1: 1: 1, \mathrm{w} / \mathrm{w} / \mathrm{w}), \mathrm{M}_{3}=$ top soil + pasir $+5 \mathrm{~g}$ zeolit $(1: 1, \mathrm{w} / \mathrm{w}+5 \mathrm{~g}$ zeolit $)$, $\mathrm{M}_{4}=$ top soil + pasir + kompos jerami rasio $\mathrm{C} / \mathrm{N}<20+5$ g zeolit $(1: 1: 1, \mathrm{w} / \mathrm{w} / \mathrm{w}+5 \mathrm{~g}$ zeolit), $\mathrm{M}_{5}=$ top soil + pasir + kompos jerami rasio $\mathrm{C} / \mathrm{N}>20+$ zeolit $(1: 1: 1$, $\mathrm{w} / \mathrm{w} / \mathrm{w}+5 \mathrm{~g}$ zeolit).Faktor 2. Aplikasi Azotobacter chroococcum (A) yaitu $\mathrm{A}_{0}=$ Tanpa Aplikasi, $\mathrm{A}_{1}=$ Aplikasi $A$. chroococcumdosis $5 \mathrm{ml}$ dengan populasi 2 luar seperti inokulan penambat $\mathrm{N}$ sangat diperlukan untuk menyuplai ketersediaan unsur hara bagi tanaman. Inokulan yang ditambahkan adalah bakteri penambat $\mathrm{N}$ non simbiotik Azotobacter chroococcum. Fiksasi gas dinitrogen dan produksi fitohormon telah dipastikan menginduksi pertumbuhan karena ketersediaan $\mathrm{N}$ meningkat dan fitohormon menginduksi pertumbuhan akar (Hindersah dan Simarmata, 2004).

x $10^{8} \mathrm{CFU} \mathrm{mL}^{1} /$ polibag. Dengan demikian diperoleh 12 kombinasi perlakuan, dan setiap kombinasi perlakuan diulang sebanyak 3 kali, maka diperoleh 36 unit percobaan.Data hasil pengamatan kemudian dianalisis berdasarkan analisis keragaman.Apabila hasil analisis uji $\mathrm{F}$ menunjukkan perbedaan diantara perlakuan yang diujikan, maka dilanjutkan dengan Uji Jarak Berganda Duncan.

\section{Pelaksanaan Penelitian}

Pembuatan kompos jerami, Pembuatan inokulum A. chroococcum, pembuatan tempat pembibitan, persiapan media tanam, persiapan stek, penanaman dan pemeliharaan. Parameter yang diamati pada penelitian ini berupa sifat tanah $(\mathrm{pH}$, $\mathrm{C}$ organik, dan $\mathrm{N}$ total) dan pertumbuhan bibit (panjang cabang, jumlah ruas, panjang akar, kadar $\mathrm{N}$ daun, berat kering daun).

\section{HASIL DAN PEMBAHASAN}

\section{Interaksi Komposisi Media Tanam dan Aplikasi A.chroococcum terhadap Pertumbuhan stek tanaman tin}

Hasil analisis ragammenunjukkan bahwa Interaksi komposisi media tanam dan aplikasi A.chroococcum berpengaruh nyata terhadap $\mathrm{pH}$ media, $\mathrm{C}$ organik dan kadar $\mathrm{N}$ daun(Tabel 1). 
Tabel 1. Rata-rata Interaksi komposisi media tanam dan aplikasi A.chroococcum pada pengamatan $\mathrm{pH}, \mathrm{C}$ organik dan kadar $\mathrm{N}$ daun.

\begin{tabular}{|c|c|c|c|}
\hline & \multicolumn{3}{|c|}{ Parameter pengamatan } \\
\hline Perlakuan & $\mathrm{pH}$ & $\begin{array}{l}\text { Berat } \\
\text { kering } \\
\text { daun }\end{array}$ & $\begin{array}{l}\text { Kadar } \\
\mathrm{N} \\
\text { daun }\end{array}$ \\
\hline top soil + pasir + pukan sapi + 5ml A.chroococcum & $7.66 \mathrm{c}$ & $5.70 \mathrm{a}$ & $2.32 \mathrm{~b}$ \\
\hline top soil + pasir + kompos jerami $\mathrm{C} / \mathrm{N}<20+5 \mathrm{ml}$ A.chroococcum & $8.02 \mathrm{a}$ & $5.67 \mathrm{a}$ & $2.99 \mathrm{a}$ \\
\hline top soil + pasir + kompos jerami $\mathrm{C} / \mathrm{N}>20+5 \mathrm{ml}$ A.chroococcum & $7.93 \mathrm{~b}$ & $3.57 \mathrm{~b}$ & $1.77 \mathrm{~d}$ \\
\hline top soil + pasir + 5 g zeolit $+5 \mathrm{ml}$ A.chroococcum & $8.01 \mathrm{a}$ & $1.70 \mathrm{c}$ & $1.61 \mathrm{e}$ \\
\hline Top soil + pasir + kompos jerami $\mathrm{C} / \mathrm{N}<20+5 \mathrm{~g}$ zeolit $+5 \mathrm{ml}$ A.chroococcum & $7.39 \mathrm{e}$ & $1.60 \mathrm{~d}$ & $2.09 \mathrm{~b}$ \\
\hline top soil + pasir + kompos jerami $\mathrm{C} / \mathrm{N}>20+5 \mathrm{~g}$ zeolit $+5 \mathrm{ml}$ A.chroococcum & $7.49 \mathrm{~d}$ & $3.57 \mathrm{~b}$ & $2.01 \mathrm{c}$ \\
\hline
\end{tabular}

Ket : Angka pada kolom yang sama dan diikuti oleh huruf yang sama tidak berbeda nyata pada taraf $5 \%$ menurut uji DMRT

\section{pH media}

$\mathrm{pH}$ tertinggi pada media top soil + kompos jerami $\mathrm{C} / \mathrm{N}<20$ dan media + zeolit (8.01), terendah pada media + kompos jerami $\mathrm{C} / \mathrm{N}<20+5 \mathrm{~g}$ zeolit (7.39). ). Hal ini disebabkan karena penambahan kompos jerami, sehingga aktifitas mikroorganisme tanah meningkat. Hal ini didukung dengan hasil pengamatan populasi A.chroococcum

\section{Berat Kering daun}

Berat kering daun tertinggi pada media + pukan sapi $(5.70 \mathrm{~g})$ dan tidak berbeda nyata dengan media + kompos jerami $\mathrm{C} / \mathrm{N}<20$ $(5.67 \mathrm{~g})$ dan terendah pada media + kompos jerami $\mathrm{C} / \mathrm{N}<20+5 \mathrm{~g}$ zeolit.Pemberian kompos pupuk kandang sapi dan kompos jerami sangat mempengaruhi berat kering daun pada stek tanaman tin. Berat kering daun berkorelasi positif nyata dengan kadar $\mathrm{N}$ daun $(\mathrm{r}=0.68)$. Nitrogen merupakan merupakan unsur makro yang banyak dibutuhkan ditubuh tanaman bersama

$\mathrm{N}$ daun tertinggi pada media dengan aplikasi A.chroococcum terdapat pada kombinasi media + kompos jerami $\mathrm{C} / \mathrm{N}<20$ $(2.99 \%)$, terendah pada media $+5 \mathrm{~g}$ zeolit $(1.61 \%)$, Tingginya $\mathrm{N}$ daun pada media dengan penambahan kompos jerami dengan dekomposer T.harzianum dan aplikasi $5 \mathrm{ml}$ A.chroococcum dikarenakan pemberian pada media + kompos jerami $\mathrm{C} / \mathrm{N}<20$ lebih tinggi dibandingkan media lain. Penambahan kompos jerami dapat meningkatkan kandungan bahan organik dalam tanah sehingga kapasitas tukar kation juga meningkat dan dapat menyangga $\mathrm{pH}$ tanah.

C,H,O,P dan K. Menurut Mahfud et al., (2006), kompos memberikan unsur nitrogen organik, unsur ini berperan dalam meningkatkan kandungan klorofil dalam daun dan secara tidak langsung berfungsi dalam proses fotosintesis yang lebih baik. Hasil fotosintesis, menghasilkan fotosintat, apabila terakumulasi dalam jumlah yang besar menyebabkan bobot kering daun lebihbesar.

\section{Kadar N daun}

kompos jerami akan memperbaiki sifat fisik, kimia dan biologi tanah sehingga akar tanaman akan dengan mudah mengambil hara dan mengeluarkan eksudat akar seperti gula dan pati yang digunakan oleh A.chroococcum sebagai sumber energi, sehingga A.chroococcum aktif bekerja memfiksasi $\mathrm{N}$ dan $\mathrm{N}$ yang di fiksasi akan 
menambah $\mathrm{N}$ dalam tanah melalui matinya A.chroococcum dan terdekomposisi. Menurut Isminarni et al., (2007), bahan organik merupakan sumber energi dan mineral bagi Azotobacter sp. dan mikroba tanah lainnya yang sangat diperlukan untuk mendukung perkembangan populasi dan aktifitas dalam fiksasi $\mathrm{N}_{2}$ atmosfer. peranan mikroorganisme Azotobacter sp yang dapat membantu penyediaan hara $\mathrm{N}$ yang diambil dari udara bebas. Dengan bertambahnya unsur hara $\mathrm{N}$ di dalam tubuh tanaman, maka organ yang menunjukkan respon adanya hara $\mathrm{N}$ yang banyak adalah daun, dimana $\mathrm{N}$ dibantu $\mathrm{Mg}$ berperan dalam pembentukan klorofil daun.

Hasil analisis ragam menunjukkan bahwa interaksi komposisi media tanam dan aplikasi A.chroococcum tidak berpengaruh nyata terhadap kadar Corganik, $\mathrm{N}$ total media,panjang cabang, jumlah ruas dan saat munculnya tunas (Tabel 2.).

Tabel 2. Rata-rata kadar $\mathrm{C}$ organik, $\mathrm{N}$ total, muncul tunas, panjang cabang dan jumlah ruas pada berbagai komposisi media

\begin{tabular}{|c|c|c|c|c|c|}
\hline \multirow[b]{2}{*}{ Perlakuan } & \multicolumn{5}{|c|}{ Parameter } \\
\hline & $\begin{array}{l}\text { Kadar C } \\
\text { organik }\end{array}$ & $\mathrm{N}$ total & $\begin{array}{l}\text { Muncul } \\
\text { tunas }\end{array}$ & $\begin{array}{l}\text { Panjang } \\
\text { cabang }\end{array}$ & $\begin{array}{l}\text { Jumlah } \\
\text { Ruas }\end{array}$ \\
\hline top soil + pasir + pukan sapi & $1.69 \mathrm{a}$ & $0.19 \mathrm{a}$ & 16 & $24.17 \mathrm{a}$ & $12.83 b$ \\
\hline top soil + pasir + kompos jerami $\mathrm{C} / \mathrm{N}<20$ & $1.08 \mathrm{c}$ & $0.12 \mathrm{e}$ & 21 & $19.17 \mathrm{~b}$ & $11.67 d$ \\
\hline top soil + pasir + kompos jerami C/N>20 & $1.06 \mathrm{c}$ & $0.13 \mathrm{~d}$ & 20.67 & $17.00 \mathrm{~d}$ & $9.00 \mathrm{e}$ \\
\hline top soil + pasir +5 g zeolit & $0.56 \mathrm{~d}$ & $0.09 \mathrm{f}$ & 16 & $13.67 f$ & $12.50 \mathrm{c}$ \\
\hline $\begin{array}{l}\text { top soil + pasir + kompos jerami } \mathrm{C} / \mathrm{N}<20 \\
+5 \text { g zeolit }\end{array}$ & $1.28 \mathrm{~b}$ & $0.14 \mathrm{c}$ & 18.67 & $17.50 \mathrm{c}$ & $13.67 \mathrm{a}$ \\
\hline $\begin{array}{l}\text { top soil + pasir + kompos jerami } \mathrm{C} / \mathrm{N}>\mathbf{2 0} \\
+5 \text { g zeolit }\end{array}$ & $1.22 b$ & $0.15 b$ & 24.33 & $17.33 \mathrm{e}$ & $13.67 \mathrm{a}$ \\
\hline
\end{tabular}

Ket : Angka pada kolom yang sama dan diikuti oleh huruf yang sama tidak berbeda nyatapada taraf 5\% menurut uji DMRT

\section{Kadar C organik}

Hasil analisis ragam menunjukkan bahwa interaksi komposisi media tanam dan aplikasi A.chroococcum tidak berpengaruh nyata terhadap kadar Corganik. Pengaruh sangat nyata terdapat pada perlakuan tunggal komposisi media tanam. Kadar C organik tertinggi pada komposisi media top soil + pasir + pupuk kandang sapi (1.69\%). Penambahan bahan organik ke dalam tanah menyebabkan aktivitas mikroorganisme akan meningkat dan proses perombakan bahan organik yang menghasilkan karbon juga akan meningkat Hal ini sesuai dengan hasil penelitian Syukur dan Indah (2006), bahwa aplikasi kompos dan pupuk kandang dapat meningkatkan kandungan $\mathrm{C}$ organik tanah. Nilai $\mathrm{C}$ organik berkorelasi positif nyata dengan nilai $\mathrm{N}$ total $(\mathrm{r}=0.97)$. Dengan meningkatnya $\mathrm{C}$ organik dalam media sebagai sumber energi bagi mikroorganisme yang berperan dalam proses mineralisasi sehingga $\mathrm{N}$ total media akan meningkat dan meningkatkan tananam dalam menyerap hara sehingga akan berpengaruh terhadap panjang cabang dan konsentrasi $\mathrm{N}$ di daun tanaman tin. Jumlah karbon organik terendah pada komposisi media + zeolit yaitu $0.56 \%$. Rendahnya nilai $\mathrm{C}$ organik media tersebut menandakan bahwa kandungan bahan organik pada media juga rendah, karena 
pada media tersebut hanya terdiri dari komposisi top soil dengan nilai $\mathrm{C}$ organik $1.09 \%$ (rendah), pasir yang tidak mengandung hara dan zeolit yang hanya

Hasil analisis ragam menunjukkan bahwa interaksi komposisi media tanam dan aplikasi A.chroococcum tidak berpengaruh nyata terhadap $\mathrm{N}$ total.Pengaruh sangat nyata terdapat pada perlakuan tunggal komposisi media tanam.menunjukkan $\mathrm{N}$-total tertinggi pada perlakuan komposisi media + pukan sapi yaitu $(0,19 \%)$ dan terendah pada media +5 g zeolit yaitu $(0,09 \%)$. Komposisi media + kompos jerami $\mathrm{C} / \mathrm{N}>20+5 \mathrm{~g}$ zeolit lebih tinggi $\mathrm{N}$-totalnya $(0.15 \%)$ dibandingkan media + kompos jerami $\mathrm{C} / \mathrm{N}<20+5$ g zeolit $(0.14 \%)$, perlakuan media + kompos jerami $\mathrm{C} / \mathrm{N}>20(0.13 \%)$ dan media + top soil + pasir + kompos jerami $\mathrm{C} / \mathrm{N}<20(0.12 \%)$ lebih kecil $\mathrm{N}$-totalnya dibandingkan dengan media + kompos jerami C/N $<20+5$ g zeolit (Tabel 1). Nilai $\mathrm{N}$ - Total tertinggi yaitu pada komposisi media + pupuk kandang sapi yaitu $(0.19 \%)$, dan terendah pada media +5 g zeolit yaitu $(0.09 \%)$. Hal ini diduga karena hasil analisa laboratorium menunjukkan bahwa kandungan $\mathrm{N}$-total dalam top soil $0.09 \%$ dan N-total pupuk kandang sapi $0.69 \%$. Hasil analisa kandungan $\mathrm{C} / \mathrm{N}$ pupuk kandang sapi 13.13 yang sesuai dengan $\mathrm{C} / \mathrm{N}$ tanah sehingga hara yang terkandung didalam pupuk kandang sapi akan cepat tersedia bagi tanah karena telah terdekomposisi secara

\section{Muncul Tunas}

Hasil analisis ragam menunjukkan bahwa interaksi antara komposisi media tanam dan aplikasi A.chroococcum tidak berpengaruh nyata terhadap waktu munculnya tunas. Waktu munculnya tunas paling cepat pada perlakuan komposisi media tanam + pukan sapi (15.00 hari) dan paling lama pada komposisi media + kompos jerami $\mathrm{C} / \mathrm{N}>20+5 \mathrm{~g}$ zeolit yaitu (23.83 hari). Perlakuan belum bisa mempengaruhi waktu muncul tunas stek, karena dalam prosesnya masih mengandung $\mathrm{Na}, \mathrm{K}$ dan $\mathrm{Ca}$ sehingga sumber karbon organik hanya diperoleh dari media top soil.

\section{N Total}

sempurna sehingga dapat melepaskan $\mathrm{N}$ bagi tanah. Hal ini sesuai dengan pernyataan Hanafiah (2005) yang menyatakan bahwa faktor-faktor yang mempengaruhi nilai $\mathrm{N}$-total yaitu bahan organik, apabila bahan organiknya tinggi maka nilai $\mathrm{N}$-total juga tinggi, begitu pula sebaliknya.

Menurut Tisdale dan Nelson (1975) dalam Nurmaulani (2001), ketersediaan N dalam tanah selain ditentukan oleh jumlah $\mathrm{N}$-total tanah, juga berhubungan erat dengan kandungan bahan organik tanah terutama tingkat dekomposisinya $(\mathrm{C} / \mathrm{N})$. Jika kandungan karbon yang masuk dalam tanah sebagai bahan organik segar sangat banyak sedangkan jumlah nitrogen relatif sedikit, dan dengan demikian nisbah $\mathrm{C} / \mathrm{N}$ tinggi. Sebaliknya, Jika kandungan karbon yang masuk dalam tanah sebagai bahan organik segar sangat banyak sedangkan jumlah nitrogen relatif tinggi, dan dengan demikian nisbah $\mathrm{C} / \mathrm{N}$ rendah. Hal ini disebabkan sebagian $\mathrm{N}$-tersedia digunakan oleh mikroorganisme dalam perombakan bahan organik.Hampir semua unsur hara makro yang dibutuhkan tanaman seperti N, $\mathrm{P}, \mathrm{K}, \mathrm{Ca}$ dan $\mathrm{S}$ serta unsur hara mikro diperoleh dari pelapukan bahan organik (Hasibuan, 2008).

menggunakan cadangan makanan yang disimpan dalam tubuh stek. Menurut Sofyan dan Muslimin (2006) stek yang berasal dari alam memiliki potensi kandungan cadangan makanan minim lebih aktif berkonsentrasi untuk membentuk perakaran yang luas guna memperoleh cadangan makanan tambahan yang selanjutnya dipergunakan untuk pembentukan tunas. 


\section{Panjang Cabang}

Hasil analisis ragam menunjukkan bahwa interaksi komposisi media tanam dan aplikasi A.chroococcum tidak berpengaruh nyata terhadap panjang cabang.Pengaruh sangat nyata terdapat pada perlakuan tunggal komposisi media tanam. Panjang cabang tertinggi perlakuan komposisi media tanam + pukan sapi $(24.17 \mathrm{~cm})$, dan terendah pada media $+5 \mathrm{~g}$ zeolit $(13.67 \mathrm{~cm})$. Panjang cabang media tanam + pukan sapi $(24.17 \mathrm{~cm})$, berbeda dengan komposisi media + kompos jerami $\mathrm{C} / \mathrm{N}<20 \quad(19.17 \mathrm{~cm})$, berbeda dengan komposisi media + kompos jerami $\mathrm{C} / \mathrm{N}<20$ $+5 \mathrm{~g}$ zeolit $(17.50 \mathrm{~cm})$, berbeda dengan komposisi media + kompos jerami C/N>20 $(17.00 \mathrm{~cm})$, berbeda dengan komposisi media + kompos jerami C/N>20 + 5 g zeolit $(17.33 \mathrm{~cm})$. Panjang cabang stek tertinggi

Hasil analisis ragam menunjukkan bahwa interaksi komposisi media tanam dan aplikasi A.chroococcum tidak berpengaruh nyata terhadap jumlah ruas.Pengaruh sangat nyata terdapat pada perlakuan tunggal komposisi media tanam.Jumlah ruas terbanyak pada perlakuan komposisi media tanam + kompos jerami $\mathrm{C} / \mathrm{N}<20+5 \mathrm{~g}$ zeolit $(13.67$ ruas) dan pada komposisi media tanam + kompos jerami $\mathrm{C} / \mathrm{N}>20+5 \mathrm{~g}$ zeolit $(13.67$ ruas). Jumlah ruas pada komposisi media tersebut berbeda dengan komposisi media + Pukan sapi (12.83 ruas), berbeda dengan komposisi media +5 g zeolit (12.50 ruas), berbeda dengan komposisi media + kompos jerami $\mathrm{C} / \mathrm{N}<20$ (11.67 ruas), dan berbeda dengan komposisi media + kompos jerami $\mathrm{C} / \mathrm{N}>20$ (9.00 ruas). Jumlah ruas terbanyak pada komposisi media + kompos jerami $\mathrm{C} / \mathrm{N}<20+5$ g zeolit dan media + kompos pada media + pukan sapi $24.17 \mathrm{~cm}$, dan terendah pada komposisi media $+5 \mathrm{~g}$ zeolit yaitu $13.67 \mathrm{~cm}$ (Tabel 2). Hal ini diduga karena komposisi media tanam yang terdiri dari tanah pasir dan pupuk kandang sapi dengan jumlah seimbang dapat memberikan struktur media yang baik bagi pertumbuhan akar tanaman tin.Chairani (2006) menyatakan bahwa pupuk kandang sapi nyata meningkatkan tinggi tanaman, jumlah anakan, berat kering bagian atas dan berat kering 1000 butir pada tanaman padi.Dalam hal ini bahan organik berperan terhadap sifat-sifat tanah seperti meningkatkan KTK tanah, $\mathrm{pH}$ tanah, $\mathrm{P}$ tersedia dan $\mathrm{P}$ potensial tanah, sehingga ketersediaan unsur hara bagi tanaman semakin meningkat.

\section{Jumlah Ruas}

jerami $\mathrm{C} / \mathrm{N}>20+5 \mathrm{~g}$ zeolit yaitu 13.67 ruas dan terendah pada media + kompos jerami $\mathrm{C} / \mathrm{N}<20$ yaitu 9.00 ruas. hal ini diduga karena media dengan kompos jerami merupakan media yang mengandung bahan organik tinggi sehingga media tersebut memiliki porositas dan daya simpan air tinggi. Jerami padi juga dapat dijadikan sebagai granulator yaitu memperbaiki struktur tanah, unsur hara $\mathrm{N}, \mathrm{P}, \mathrm{S}$, unsur mikro dan lain-lain, selain itu jerami juga dapat menambah kemampuan tanah menahan air, menahan energi hara sehingga kapasitas tukar kation tanah menjadi tinggi dan sebagai sumber energi bagi mikroorganisme (Lesman, 2008). Banyaknya jumlah ruas akan mempengaruhi produktifitas tanaman tin, karena buah tin keluar dari buku yang terletak antara ruas-ruas. 


\section{SIMPULAN}

Interaksi komposisi media tanam dan aplikasi A.chroococcum berpengaruh nyata terhadap parameter $\mathrm{pH}$ media, berat kering daun dan kadar $\mathrm{N}$ daun, sedangkan perlakuan tunggal komposisi media tanam berpengaruh nyata terhadap $\mathrm{C}$ organik, $\mathrm{N}$ total, panjang cabang, jumlah ruas, dan tidak berpengaruh nyata terhadap waktu munculnya tunas. Penggunaan komposisi media tanam top soil + pasir + kompos jerami $\mathrm{C} / \mathrm{N}>20$ dapat meningkatkan jumlah ruas yang akan mempengaruhi produksi buah tin

\section{DAFTAR PUSTAKA}

Bernas, S. M. E., Komara, M. B., Prayitno., dan S. N. A. Fitri. 2005. Pengaruh Zeolit dan Pupuk NPK Terhadap Sifat Fisik Tanah Ultisol Berpasir dan Produksi Kedelai. Prosiding Seminar Nasional Lembaga Pengembangan Wilayah Kering I 1999. Universitas Riau.

Chairani.2006. Pengaruh Posfor dan Pupuk Kandang Kotoran Sapi terhadap Sifat Kimia Tanah dan

Pertumbuhan Tanaman Padi (Oryza sativa) pada Lahan Sawah Tanah Tadah Hujan di

Kabupaten Langkat, Sumatera Utara. Jurnal Penelitian Pertanian 25(1): 8-17.

Flaishman, M., V. Rodov, and E. Stover. 2008. The Fig: Botany, Horticulture, and Breeding. Horticultural Reviews, Volume 34 ISBN 9780470171530. John Wiley \& Sons, Inc. USA.

Hanafiah, K. A. 2005. Dasar-dasar Ilmu Tanah.Raja Grafindo Persada. Jakarta.

Hasibuan, B. E. 2008. Pupuk dan Pemupukan, FP- USU, Medan.

Hindersah, R. dan T. Simarmata. 2004. Kontribusi Rhizobacteri Azotobacter dalam meningkatkan
Kesehatan Tanah Melalui Fiksasi $\mathrm{N}_{2}$ dan Produksi Fitohormon di Rizosfer. Jurnal Natur Indonesia. 6 : 127 - 133 .

Mahfudz, Isnaini dan Moko, $\mathrm{H}$. 2006.Pengaruh Zat Pengatur Tumbuh dan Media Tanaman terhadap Pertumbuhan Stek Pucuk Merbau. Jurnal Penelitian Hutan Tanaman. Vol.3 No.1 Maret 2006, 25-34.

Nurmaulani M. 2001. Hubungan antara Komunitas Vegetasi dengan Kesuburan Tanah dan Ketebalan Gambut (Studi Kasus di HPH PT Diamond Raya Timber, Bagan Siapi-api, Riau) [Skripsi]. Bogor: Fakultas Kehutanan, Institut Pertanian Bogor.

Sobir dan M. Amalya. 2011. Bertanam 20 Buah Koleksi Eksklusif. Penerbit PT.Penebar Swadaya. Jakarta. 208 hal.

Sofyan, A. dan I. Muslimin.2007.Pengaruh Asal Bahan dan Media Stek Terhadap Pertumbuhan Stek Batang Tembesu (Fragraea fragarance ROXB). Prosiding Expose Hasil-hasil penelitian. Balai LitbangTanaman Palembang

Supriadi, S 2006. Peluang Usaha dan Solusinya http://www.Majalah Pengusaha.com 2006[ 20 Maret 2009].

Syakir, M., M.H. Bintoro, dan Y.D. Amrin. 1992. Pengaruh Berbagai Zat Pengatur Tumbuh dan Bahan Stek terhadap Pertumbuhan

Stek Cabang Buah Lada. Jurnal Littri Puslitbang Perkebunan Vol. 19 (3-4): 59-65. Bogor.

Syukur, A dan N. M. Indah.2006. Kajian Pengaruh Pemberian Macam Pupuk Organik Terhadap Pertumbuhan Dan Hasil Tanaman Jahe Di Inceptisol Karanganyar. 
Jurnal Ilmu Tanah Dan Lingkungan Vol 6 (2) : 124-131

Tisdale, S. H. L and Nelson. 1975. Soil Fertily and Fertilizer. Mc Millanco, New York.
Tisdale, S. L., Nelson, W.L. and Beaton, J.D. 1990. Soil fertility and fertilizer.4thed. The Macmilan Co., New York. 
Vol.3, No.1. April 2016. (10) : 91- 99 